\title{
Defamation in English and Arabic: A Pragmatic Contrastive Study
}

\author{
Basim Yahya Jasim Algburi $^{1} \&$ Zainab Kadim Igaab ${ }^{2}$ \\ ${ }^{1}$ University of Mosul, College of Arts, Department of English, Iraq \\ ${ }^{2}$ University of Thi-Qar, College of Education for Humanities, Department of English, Iraq \\ Correspondence: Zainab Kadim Igaab, University of Thi-Qar, College of Education for Humanities, Department \\ of English, Iraq. Tel: 00964-7800-045-735. E-mail: zaineb-k@utq.edu.iq
}

Received: April 29, 2021; Accepted: May 10, 2021; Published: May 12, 2021

\begin{abstract}
Defamation is one of the verbal offences in which the plaintiff is accused of a certain wrongful act by one of the ways of publicity. If that wrongful act is proved, then the accused will be punished by law or lowered by his/her home people. Defamation is surely accusing another person of a wrongful act. Accusing can be done by any spoken or written ways whether truthful or doubtful. The purpose beyond those ways is to make those accusations about the victim true in the people's mind even if they are temporarily made. The aim of this study is to elucidate if there is a similarity or a difference between English and Arabic in terms of defamation. It has been hypothesized that both languages are different from each other in terms of the topic under investigation. This study arrives at: In terms of defamation, English and Arabic are similar to each other in having speech acts, grammatical referencing, conveyed meaning, malicious meaning, and discourse structure and framing with intentionality. English defamation cases include speech acts more than Arabic defamation ones.
\end{abstract}

Keywords: contrastive analysis, defamation, pragmatics

\section{Introduction}

It is not easy to understand or apply defamation law. It is not always simple to avoid conflicts between the right to free speech and the right to have protection against unwarranted damage to reputation caused by false accusation. Evidence of damage to reputation in the community which results from the alleged defamation is an essential element in any legal action of defamation but it is not easy to prove (Shuy, 2000: 14). For example, the defendant accuses an official of embezzlement of the government money; a judge of accepting a bribery for a certain lawsuit, etc.

\subsection{Introduce the Problem}

The researchers have been faced with a problem which is that no study has dealt with defamation pragmatically and contrastively. This is the reason beyond its originality. The research question of this study is that which similarities and differences can be found between English and Arabic in terms of defamation?

\subsection{Aims of the Study}

This study aims at explaining to what extent English and Arabic are similar or different from each other in terms of defamation.

\subsection{Hypothesis of the Study}

The study hypothesis is that English and Arabic are different from each other in terms of defamation.

\section{Literature Review}

\subsection{Defamation Studied Legally}

According to English and Iraqi legislators, defamation is one of the crimes against the person's sacredness, consideration, social rank, feelings and honour. Defamation is a person's accusation of a certain wrongful act by one of the ways of publicity. If that wrongful act is proved, then the accused will be punished by law or lowered by his/her home people. It is described as being the tort or legal wrong of communicating a falsehood which injures another's reputation (Mousa, 2012: 262; Naseef, 2010: 118; Al-Durra, 2009: 246-247 and Duffy, 1983: 267).

A falsehood is normally a false assertion of facts in a defamation case. That fact is either an actual, already existing condition or an occurrence. For example, a statement uttered for an employee is "an employee was fired", but in fact the employee had been quit; "an employee was demoted", when, in fact, an employee was transformed 
according to his/her desire. Such misstatements of existing, provable matters construct falsehoods which support a defamation charge (Duffy, 1983: 270-271).

Accusing can either be oral by uttering words or expressions, written by hand or printed on any material (paper, wood, cloth), paintings or signals. It is not sufficient to accuse the victim of a wrongful act but that act must be certain and limited in a certain place at a certain time in addition to the circumstances where that act happened (Ahmed, 2013: 16-17; Al-Musawy, 2010: 23-25 and Al-Durra, 2009: 249).

There should be actual malice in publishing false statements. Actual malice was defined as "knowledge that the information was false", or that it was published with "reckless disregard of whether it was false or not". Defamation can strongly be proved if malice or ill will could be proved and the accusation could be shown to be false (Shuy, 2000: 13).

Defamation can either be public or non-public. It also includes verbal abuse. In law, the punishment of defamation is much more than that of verbal abuse. Defamation consists of three elements:

\section{a. Actus reus}

The actus reus of this crime consists of the act which is represented by an accusation of a certain wrongful act that is the topic of the actus reus in addition to the publicity.

\section{b. Publicity}

There is no defamation without accusing a certain wrongful act publically against the victim. This element is distinguished for defamation since this crime is to be dangerous due to uttering bad words or expressions publically (Al-Musawy, 2010: 23; 33-34; Naseef, 2010: 119-125 and Al-Durra, 2009: 247-253).

\section{c. Mens rea}

Defamation is deliberate with the availability of the criminal intention. The defendant intends to utter the words and expressions against the victim with knowing that if what is uttered is true, the victim must be punished by law or lowered by home people. The defendant must also know that uttering those words and expressions will damage the victim's reputation, consideration and honour. But if those words and expressions are not really bad, so the defendant's criminal intention must be proved (Al-Musawy, 2010: 47-50; Naseef, 2010: 125-126; Al-Durra, 2009: 254 and Al-Qulaly, 1948: 131-132).

Defamation is of two types: libel and slander. Libel indicates written defamation, whether in newspapers, magazines, books, electronic messages, or distributed memos or letters while slander indicates spoken defamatory expressions like speeches, sermons, or other public oral presentations (Shuy, 2000: 11-12).

\subsection{Defamation Studied Pragmatically}

Defamation, as defined by Garner (2009: 479-480), Betti and Al-Jubouri (2015: 46), (Rolph (2008: 62-63), Ibrahim (1997: 260) and Calow (1995: 199), is the publication of a statement with a tendency to lower a person in the estimation of right-thinking members of society in general; or with a tendency to make them shun or avoid that person. So, they will not associate with him/her or deal with in any aspect of life like the business. Defamation in a form of a statement or communication has a tendency to harm a person's reputation by being subject to public contempt, disgrace, or ridicule. It pushes the people to carry feelings of hatred, contempt, ridicule, fear or dislike towards that person. With defamation, a person will be injured in his/her social reputation and it ends in a loss of receiving respectful consideration from the world.

Tiersma (1987: 304) explains that defamation is "a variety of language regulation that prohibits the uttering of certain types of speech, or more precisely, allows those types only in very specific circumstances." Such a regulation includes how an individual is related to the community because defamation is defined as a public accusation of wrongdoing which is a linguistic act that makes the status of an individual low, who has infringed community norms.

A man should keep his superiority, honour and reputation. The core of a man's identity, especially his manhood, is honour. Men need to prove that they are men in contrast with the women who do not need to prove. So, men need to protect and keep their status against any offensive claims by others about their honour depending on standards of conduct. The key elements of honour in those days are social rank, fame, character, and reputation (Shuy, 2000: 16-18 and Al-Timimy, 1982: 1-3).

To regard a person defamatory, a plaintiff's reputation must be injured by a falsehood, i.e., the plaintiff's esteem, respect, good will or confidence in which he/she is generally held, are diminished; derogatory or unpleasant 
feelings or opinions are expressed against that person (Naseef, 2010: 120; Bies and Tripp, 1993: 315 and Duffy, 1983: 269).

Obviously, negative or derogatory information is transformed by most defamatory falsehoods. For example, when an employee is falsely stated as 'dishonest' , 'a poor manager', or a student to his teacher 'a briber', his esteem or confidence where he is held, will be diminished, but when that employee is falsely stated as 'honest' or 'a great manager' with irony or sarcasm, this will not diminish his reputation and it is not defamatory (Betti, 2019: 167 and Duffy, 1983: 269-270).

Laws of defamation are created by societies to protect people from those who injure their reputation to settle issues of truth or falsehood and reputational harm which results from defamatory statements (Kenyon, 2010: 697 and Amponsah, 2004: 2).

In England, in the libel case, it should be proved by the defendants that their libel allegations against them are false. In British courts, when the accusation is made, the accusers have a distinct advantage over the accused because they should prove their innocence. British libel law is criticized as being so sympathetic to allegations of libel in a way which has made London the centre of "libel tourism" (Shuy, 2000: 10).

In the English and American communities, there are two opposite points of view adopted by two groups: majorities and minorities. The former believes in the freedom of speech while the latter is against it. But in the Arabic community, defamation is an act done against society, law and religion. It negatively affects the Arabic beliefs, traditions and values. It is forbidden and refused by all because it is hatred and disgusting.

Defamation must be explained in terms of both illocutionary force (see: Austin, 1962: 99-108) and perlocutionary effect (see: Searle, 1969: 54-71). In the latter, the receiver's character or reputation is affected and in the former, the speaker's intent is shown. So, a defamation claim depends on both the receiver's feelings concerning being defamed and the way the sender's message is said or written. Thus, the message should linguistically be analysed.

\subsubsection{Interpretation}

To prove any defamation claim is uttering words which are defamatory and they should refer to the claimant (plaintiff). It is too essential to ascertain the meaning of those words. Of course, it is possible for a defendant to find a justification for the meaning of words differently from that meaning of what the claimant alleges that those words convey. So, the key question is asserting the correct meaning. Defamatory words must be said in their ordinary natural meaning. One of the requirements for imputations of crimes is certainty. The second one is malice. Writing contains more malice than speaking (Mitchell, 2005: 31-34).

As a fundamental approach, defamatory words can be interpreted by asking how an ordinary bystander understands those words. In this fundamental principle, there are sub-rules and refinements which emerge. For example, a proper and natural meaning can be given by the written material according to the ordinary rules for the interpretation of written instruments, in comparison with, slander canons of construction which are suitably applicable to contracts and statutes which are not depended upon as a guide to the reasonable interpretation of angry and ill-chosen words. Through the development, the attributes of the reasonable person are emphasized. But the interpretation cannot be limited to logical meanings since illogical conclusions can sometimes be drawn by ordinary people. On the other hand, the reasonable meaning of the language is looked for by the courts. The claimant cannot depend on an interpretation which is based on the assumption that some readers just have a look at a newspaper and they are only attracted by the pictures and headlines (ibid: 38).

\subsubsection{Defamatory Language (An Act of Accusation and Its Propositional Content)}

There are two ways to approach defamation. The first is in terms of its effect on the target or his/her reputation and the other in terms of the act of the speaker. The defamatory language requires - or ought to require that the speaker achieves the illocutionary act of accusing. So, an utterance is said with a force of an accusation in a way when it makes someone be responsible for an act or a state of affairs. That force of accusation becomes clear when a speaker states, "I accuse P of A," by using a performative phrase in the first person with the present tense. With this particular force, an accusation must have a specific propositional content. It should attribute responsibility to a specific person for a discreditable or blameworthy act or state of affairs.

To support a defamatory language as being accusatory, it can exist in judicial opinions. Words like 'accuser and accusation' are used by judges to describe libelous or slanderous communications (Tiersma, 2015: 159). Judges and others use the verb 'accuse' to describe charges made against another, but that verb is rarely used by accusers in their accusations. For example, to preface clearly the holding of an opinion, a judge says 'we hold', while an accuser does not start the force of an accusation with 'I accuse'. So, it is essential to ask about the speaker's intent in making the utterance whether he/she tries to make someone responsible for a discreditable act or a state of 
affairs. For instance, when a store manager tells a police officer, "That fellow took a radio without paying for it". Such an utterance is not like the others but it is an accusation of theft. Another example is that a woman whose house had burned down is asked by an insurance agent "How did you set the fire?", the true force of that utterance is not a question but an accusation of arson. Thus, what is important is that an utterance should be expressible with an explicit performative phrase (I accuse) or its equivalent (ibid: 160).

There is a close relation between the illocutionary act of accusing, and confession and blame. When a person confesses, s/he necessarily attributes the responsibility of a bad act to him/herself. Similar to an act of accusing, an act of confession is done in a public way. One must confess before witnesses while blaming usually entails an un-communicated attribution of responsibility (Al-Seady, 2002b: 14). For example, one can blame himself or someone else for a responsible act but this attribution may not be public, it may be mental, but it can become public if it is announced (Tiersma, 2015: 160).

\section{The Model for Defamation Analysis}

English and Iraqi-Arabic defamation cases will be analysed in a model suggested by Shuy (2000):

\section{Accuracy of the Alleged Defamation Evidence}

Discourse analysis is not just the study of language. It is a way of looking at language that emphasizes how people use it in real life (Betti and Mahdi, 2020: 71).

The discourse context in which the alleged defamation takes place can be analyzed but not accurately since it is difficult to prove that the offending language includes actual malice or a reckless disregard for the truth (Shuy, 2000: 31). So, there is a controversy about its accuracy. But if the quote had been taped recording, the accuracy would exist.

\section{Grammatical Referencing}

If the language whether spoken or written is clear and grammatically explicit, many defamation cases are easy to resolve. But in actuality, things do not happen in the ways we expect. For example, modulation, which "denotes using models and other constructions to refer to such functions as ability, obligation, permission and willingness, possibility, necessity and obligation" (Betti and Igaab, 2018: 30), is a crucial factor.

Many defamation cases start with disputes over whether the statement spoken or written stands for opinions or statements of fact. The speech act theory was first begun by Austin (1962) and Searle (1969) to refer to the functional dimension of language. The theory of SAs belongs to pragmatics because it requires a speaker implying (encoding) a message and a hearer inferring (decoding) that message. However, the context or situation plays an important role in the process of inferring the S's intended meaning. Furthermore, without such information, it is impossible to know the S's intended meaning (Betti and Hasan, 2020: 43).

According to Tiersma's article "The Language of Defamation" (1987: 303-350), certain issues about defamation can be resolved by the application of speech act theory. With that theory, every utterance is made up of both an illocutionary act that is related to the intended force of that utterance and a perlocutionary act which is related to the effect of the utterance on the reader or hearer. It has been noticed by Tiersma that the law of defamation has emphasized the perlocutionary effect of author's utterances on the alleged victims rather than on the illocutionary force of the author's speech acts of accusing. Writers defame when they accuse without privilege to do so or when they accuse in violation of the norms of the speech community which regulates accusations (Shuy, 2000: 33; and Betti and Igaab, 2015: 12).

\section{Conveyed Meaning}

Two types of meaning exist: referential (the formal logic of dictionary definitions) and conveyed meaning (meaning that is not explicitly stated but can naturally be implied or inferred). Sometimes, the illocutionary force relies on the context and manner in which the words are said. They are said or written with their connotation than their dictionary definitions.

In general, language is a powerful means of human communication. Via using language, the sender can deliver his/her intended meaning to the receiver. According to Grice, the communicative activity should go smoothly and straightforwardly. Thus, Grice postulates the cooperative principle. The cooperative principle says that people should be cooperative in their communication. As a result, Grice supports the cooperative principle by four maxims, which speakers should follow (Betti and Yaseen, 2020: 43-44; and Igaab and Tarrad, 2019:57).

A clever use of the speaker's or writer's conveyed meanings can take a part in attributing defamatory effects. For instance, showing only parts of the alleged defamatory text on a television screen gives the reader a chance to infer what is found in the missing parts (ibid: 34 ). 


\section{Intentionality}

The defamatory meaning of a statement depends on what that statement would mean to the community which stands for the average reader or listener. The author's intention has an important role in resolving the meaning of the words in question since that meaning is determined by the ordinary reader's response to the question (Igaab and Altai, 2018: 288-9). The issue of intentionality cannot be settled in many defamation cases. In any science, including linguistics, the person's real intentions cannot be determined but the language used by people can supply them with very useful clues as a way of help to address such questions (ibid: 35 ).

There is a way to find clues to people's intentions which is discourse analysis. For instance, the topics which the person mentions are considered as a good evidence for his intentions or what there is in his/her mind; when the topics are recycles, they show that it was the speaker's intention to introduce that topic and keep on introducing it until it is understood, appreciated or resolved; when the topic is changed, the change shows the speaker's intention not to talk about it. In the defamation cases, the linguist has a role to help resolve whether an expression is able to convey a defamatory meaning. "Unfortunately, intentions can also be misunderstood or misinterpreted" (Shuy, 2000: 36; and Igaab, 2010: 13).

\section{Malicious Language}

It is not clear to judge what is malicious and what is not. Two synonyms mentioned by Garner (1995: 545) are "intentional" and "reckless". In most defamation cases, a mistaken assumption is to give a meaning to "malicious" which is "wicked" or "evil". "Malice" which is conveyed by language takes the form of sarcasm, pejorative terms, exaggeration, and rhetorical questions. All present some evidence of the sender's heightened emotion.

Sarcasm, exaggeration, overgeneralizations, and rhetorical questions do not always lead to defamation although they contribute to the effect of defamatory expressions (ibid: 37 ).

\section{Discourse Structure and Framing}

Functional sentence perspective describes how information is distributed in sentences. It deals with the distribution of Th [theme] and Rh [rheme]. This is part of the information theory (Betti and Al-Jubouri, 2009: 8). Likewise, thematization refers to the options available for arranging the elements of a clause into theme and rheme. In this case, it is realized by the sequence of elements in the sentence or clause (Betti and Al-Jubouri, 2009: 12).

No one can see and know what there is in the speakers' minds but the topics they introduce and recycle are regarded as very good clues to their intentions. The discourse structure and framing play an important role in showing the speaker's intent.

\section{Method}

The procedures to be followed are: a theoretical background is given and then a practical side is designed.

The data of this study consists of ten complaints of defamation. Five English defamation cases and Five Arabic ones are selected to be the sample of the study under the investigation. The Arabic data is taken from judges of investigation in the court and investigators in the police centre in Thi-Qar Province and Al-Haydary and Betti (2020a). The English data is taken from English websites. Writing the examples in the Arabic section follows two steps which are translating the example into English and then transliterating it. English refers to American and British while Arabic refers to Iraqi.

\section{Results}

In the following two subsections, English and Arabic defamation cases are analysed and discussed.

\subsection{English Defamation Cases}

The legal field, to which law belongs, constitutes an independent culture with powerful vocational norms that give sense and reinforcement to the individual's behavior (Betti and Hashim, 2018: 277). In English, the study under investigation selects five defamation cases to be analysed and discussed following Shuy's (2000) model.

\subsubsection{Friedman Sues Bloomberg News}

Friedman filed a lawsuit against his former employer, Palladyne International Asset Management, and others. Publishing a news article by Bloomberg News which reported on Friedman's lawsuit made a defamation action. On the basis of Friedman's allegations, Palladyne which was a purported hedge fund based in the Netherlands, fraudulently induced him into working as its 'head of risk' to make people understand that that company was lish and an executive recruiting firm made many misrepresentations to convince him to accept this position. In November 2011, Friedman moved to the Netherlands to work for Palladyne. Then, he discovered that Palladyne was a 'kickback and money laundering operation for the former dictatorial Ghaddafi [sic] regime in Libya'. In 
February 2012, when Friedman voiced concerns to a colleague that Palladyne was not involved in legitimate investment activities and could face criminal exposure, he was "abruptly terminated with no legally cognizable explanation". On March 25, 2014, Friedman sued Palladyne and the firm which recruited him for the position, in addition to a number of their employees. He affirmed seven counts in his complaint like fraudulent inducement, etc. On March 27, 2014, Bloomberg News published an article online, entitled "Palladyne Accused in Suit of Laundering Money for Qaddafi". As a response, Friedman filed a defamation action against Bloomberg LP., its authors and editors; the Netherlands- based Palladyne and two of its senior officers and others (Al-Seady, 2002a: 27).

Speech acts: reporting fact vs. giving opinion

The theory of SAs indicates that the performance of a SA, in addition to meaning, means the performance of three kinds of acts at once:

1). the locutionary act (LA) "the act of saying something with full sense of "say",

2). the illocutionary act (IA) "the act performed in saying something", and

3). the perlocutionary act (PA) "the act performed by or as a result of saying" (Betti aand Hasan, 2020: 44).

A number of speech acts existed like claiming, alleging, arguing, requesting, accusing and apologizing in the English case no. 1.

Friedman alleged that the statements in the published article were false and caused him serious and harm which cannot be repaired:

(1) A statement that "[Palladyne] was sued in the US, for as much as \$500 million."

(2) A quote from Palladyne that "[t]hese entirely untrue and ludicrous allegations [in Friedman's earlier lawsuit] have been made by a former employee who has repeatedly tried to extort money from the company ... He worked with us for just two months before being dismissed for gross misconduct."

Friedman alleged that Palladyne was "nothing more than a façade created to conceal criminal transactions" and also alleged that he had been fired by Palladyne with "no legally cognizable explanation" after voicing his concerns to a colleague about the firm's criminal exposure.

Friedman accused the Bloomberg defendants' of negligence and recklessness. They published the article without contacting Friedman for a response and being sure of their accuracy. On the other hand, the Palladyne in the article published online accused Friedman of being extortionist. There was an indirect apology made by the Bloomberg defendants to Friedman by submitting a justification. They did not accuse Friedman of anything criminal, it is just giving an opinion. Friedman argued that it was unfair because the court has a personal jurisdiction. Its statute excluded the defamation action but Friedman said that it was unconstitutional. Friedman requested the court to enter judgement on all counts for the plaintiff.

Grammatical Referencing: Reporting Fact vs. Giving Opinion

A number of pronouns and noun phrases were mentioned in the article. The use of the plurality demonstrative 'these' followed by the two modifiers 'untrue' and 'ludicrous'; the relative pronoun 'who' which followed the noun phrase 'a former employee'; and the use of the personal subject pronoun 'he' and the personal object one 'us' were to emphasize Friedman's dishonesty towards the company where he was working (Igaab and Abdulhasan, 2018: 97).

\section{Conveyed Meaning}

The use of the defamatory statement 'for as much as $\$ 500$ million' was to convey an implied meaning which is that Friedman could have been awarded that amount if his lawsuit were successful.

The use of other defamatory statements 'repeatedly tried to extort money' and 'He worked with us for just two months before being dismissed for gross misconduct' expressed his criminal nature. There were other undisclosed facts which were still hidden and could be detrimental to his character. Committing a tortious act outside the state might cause injury to a person (Salman and Betti, 2020: 229).

\section{Malicious Language}

Palladyne's use of the word 'extort' was described as being rhetorical hyperbole and a vigorous epithet. It reflected that Friedman's intention was to get money when he filed a lawsuit against Palladyne.

Discourse Structure and Framing 
The intention of Palladyne was so clear to defame Friedman who tried to reveal its secrets. The use of 'extort' was the best signal for Friedman's criminal conducts. That's why he was dismissed after two months according to the company allegations.

As a conclusion, Friedman proved that those defamatory statements were unfair and untrue because they missed the accuracy and Bloomberg defendant should look for him to ask him personally about what was written in his complaint.

\subsubsection{A Lawsuit of a Professional Disc Jockey}

Samantha Ronson, the plaintiff, was a professional disc jockey who was regularly hired to perform at exclusive parties and events. She presented a complaint against Sunset Photo and News, LLC, and others. Sunset Photo was a 'paparazzi agency' which was specialized in collecting and distributing photographs and gossip about famous entertainers and other celebrities. Sunset Photo possessed and controlled Celebrity Babylon which was an online magazine. It published gossip about famous entertainers and celebrities.

News outlets and websites published that on May 26, 2007, celebrity actress, Lindsay Lohan was involved in a car accident. It was reported that Lohan was under suspicion for driving under the influence of alcohol; and that the police who were called to the scene found cocaine in Lohan's car. At the time of the accident, Ronson was in the car with Lohan.

\section{Grammatical Referencing}

In the article, there was an explicit and unambiguous reference to Ronson. Her name was mentioned directly six times and seven subject and object pronouns in reference to Samantha. In this regard, reference is considered one of the cohesive ties mentioned in Halliday and Hasan (1976) in addition to substitution, ellipsis and conjunctions (constituting grammatical cohesion) and reiteration and collocation (constituting lexical cohesion) (Betti and AlFartoosy, 2019: 102).

\section{Speech Acts: Reporting Fact vs. Giving Opinion}

More than one speech acts existed in this defamation case.

Samantha alleged that the defendants were of fictitious names, who caused the injuries and damages to the plaintiff.

The illocutionary act of alleging was accompanied by the perlocutionary act. She was harmed because of defendants' tortious act of publishing defamatory statements about her on the internet. Those statements were published to millions of people in the same area where Samantha lived. Those statements negatively affected Ronson's professional life as a Disc Jockey and reputation. Ronson had been damaged by their publication.

Another speech act which is accusing Ronson of planting drugs in Lohan's car and setting up Lohan for press photographers in exchange for money. That accusation was by the online magazine Celebrity Babylon by publishing an article. The article stated, inter alia:

Celebrity Babylon has learned that while her DJ pal Samantha Ronson, 29, looks like she's there to help her pal through thick and thin, she's really making a tidy profit on the side, shilling Lohan, 20, out to photographers eager to get her photo looking passed out and wasted. While an "out of it" Lohan thought she was just going home after a night out at Teddy's in Hollywood on May 27, Ronson made a side trip to a gas station. A source tells Celebrity Babylon, "The car was only down a quarter tank, and yet Samantha stopped for gas. She has a side deal with a photo agency and they paid her to make the pit stop!" If that wasn't shocking enough, sources say that it was Ronson who was holding the cocaine later found in Lindsay's car. "There were three of them crammed into the Mercedes sports car and Samantha was the one that had the cocaine with her. Lindsay later questioned her about leaving it in the car for the cops to find and Samantha blew her off." Ronson, who makes anywhere from $\$ 2.000$ to $\$ 3.000$ a night deejaying at clubs and private parties, has accumulated a substantial side income taking her pal in front of paparazzi cameras for money.

Another accusation made by another defendant who published an article on PerezHilton.com, in which the statements by Celebrity Babylon were found in addition to other statements like 'Ronson has been toxic to Lohan; 'According to news reports, Ronson has been selling out Lohan to the paparazzi".

\section{Conveyed Meaning}

One of the statements published to defame Samantha was "With friends like Samantha Ronson, Lindsay doesn't need any enemies."

Such a statement carried an implicit meaning which was Samantha was not a friend to Lohan but an enemy and she might be the only enemy for Samantha. 


\section{Malicious Language}

The statements were published with actual malice. They accuse her of a criminal activity and expose her to hatred, contempt, ridicule and obloquy since they inaccurately described Ronson as a disloyal, dishonest friend who sold out and set up her friend, Lohan for personal financial gain.

Intentionality

Defendants intended to cause harm to Ronson by public publication for unknown number of individuals who resided in the same area where Ronson lived. Those individuals represented third persons. Such a step ensured the public defamation. Involving Ronson in cocaine trading was published in seven celebrity gossip websites (Dehham, Betti and Hussein, 2021: 9).

The main topic emphasized was that there was an agreement between Ronson and a photo agency to tip the paparazzi off to her whereabouts with Lindsay. Even photo-ops for them were created.

Another topic was that the cocaine found in Lohan's car after her crash might have been Ronson's (with writing the name of Ronson in capital letters followed by an exclamatory mark) RONSON!.

Those topics indicated the defendants' intent to emphasize that Ronson wanted to sell Lohan to a photo agency for getting money. She was betrayal by guiding the paparazzi to Lohan while she was in her car beside the cocaine. Even a car accident was prepared by Samantha. Lohan thought that she would go home directly after spending a night at Teddy's in Hollywood, Ronson decided to go to the gas station although there was no need for such an additional trip.

As a conclusion, the statements published in more than one article to defame Ronson, were false and libelous.

\subsubsection{A Letter to Cease and Desist Internet Defamation}

Mr. Justin E. Leonard and his visitors on his various websites made a series of unwarranted and defamatory attacks against DirectBuy, Inc. which had been in business for over 35 and had supplied consumers with the opportunity to save on products to their homes through their members according to a programme. Its client supplied its members with access to thousands of products and provides a high level of consumer service.

Speech acts: reporting fact vs. giving opinion

Mr. Leonard's baseless accusations and his unwarranted actions damaged the well-founded reputation of DirectBuy Inc. for the quality of its services and consumer satisfaction. In addition, those accusations and actions were of adverse effect on its client's business; they caused serious and irreparable injury to it, its reputation and its business.

DirectBuy and its members threatened Mr. Leonard by telling him that its client would not stand by and allow this misconduct to continue.

Another threat was that this letter was the only chance to resolve this matter amicably.

DirectBuy Inc. demanded that Mr. Leonard and his visitors should immediately remove from all of your websites all defamatory and disparaging remarks regarding its client made by him and his visitors; they should immediately cease and desist in publishing defamatory statements about its client, whether the statements are made by him or third parties; and he should compensate its client for its attorney fees and costs.

Conveyed Meaning

Many willfully false and misleading comments were personally posted about DirectBuy Inc. client. More than one conveyed meaning was expressed through a number of defamatory statements published on a number of websites by Mr. Leonard and his visitors:

- "DirectBuy Inc. nightmare".

Through this statement, Mr. Leonard wanted to warn consumers against DirectBuy Inc. So, he made them understand that this was an advise not to deal with it because it was dangerous and it might have actions which scared them.

- "All scams are posted uncensored" and "You are reporting the following SCAM".

The above two statements meant that DirectBuy Inc. and its members are fraudulent and violate civil and criminal law.

- "Recently, we noticed a sudden influx of 4 and 5 star ratings for the DirctBuy program ... We don't know if DirectBuy is behind this or not".

This meant that they were sure that DirectBuy was behind the sudden influx of 4 and 5 star ratings. 


\section{Malicious Language}

Mr. Leonard and his visitors were malice with DirectBuy and its members by publishing the following statement: "But we do have our suspicions given the fact that the reviews came from the SAME LOCATION, say the same thing, and highlight points that most customers wouldn't be concerned with".

They were mocking at it to make it be lower in its consumers' eyes.

\subsubsection{A Lawsuit of Gaspar Physical Therapy, INC and an Individual}

On September 6, 2017, a California corporation and Brian Stone filed a complaint alleging defamation, intentional infliction of emotional distress, and negligence against Dave Roberts and others because the latter distributed two double- sided printed campaign advertisements ('the mailers') to approximately fifty to fifty-five thousand households in the same area where the former resided.

Speech acts: reporting fact vs. giving opinion

Plaintiffs alleged that the two statements distributed on the front side of the October 14 mailer were defamatory on or about October 14, 2016:

1. "KRISTIN GASPAR COMPANY SETTLED A LAWSUIT COMPENSATING VICTIMS WHO SUED FOR MALPRACTICE AND ELDER ABUSE."

2. "Kristin Gaspar has a long history of shady business practices... [she] operates a medical business known for malpractice, elder abuse, and negligence."

3. The third statement distributed on the back of the October 14 mailer was:

"Kristin Gaspar's company broke her patient's trust."

Other mailers were distributed again with the same statements.

Gaspar Physical Therapy and Stone denied all of the allegations against them.

Gaspar Physical Therapy and Stone agreed to a waiver of any claim for costs they may have been able to recover from the plaintiff in exchange for plaintiff voluntarily dismissing the action.

Plaintiffs contended that statements in the defendant's mailer regarding Gaspar "compensating victims" were false and libelous and caused both financial and reputational harms.

\section{Grammatical Referencing}

The defendants distributed the mailers more than one time with the same defamatory statements in which words with capital letters were written; the name Kristin Gaspar was mentioned in every statement with using the pronoun (she) to refer to a woman not a man. All this was done to defame that company and its officials and workers (Igaab and Kareem, 2018: 98).

\section{Conveyed Meaning}

In the first statement, Kristin Gaspar company had a number of victims who filed a complaint against it for malpractice and elder abuse.

Kristin Gaspar was distinguished with malpractice, i.e. bad behaviours with its clients and elder abuse, i.e. with less respect towards its patients.

The second statement indicated that although that company should be human but it worked for business purposes. So, there was no humanity but trade with the patients' spirits.

The third statement tried to make its clients feel doubtful of it and miss their confidence with it.

\section{Malicious Language}

Defamatory statements expose any person to hatred, contempt, ridicule, or obloquy, or causes him to be shunned or avoided, or has a tendency to injure him in his occupation or injure the business reputation.

\subsubsection{A cancer researcher sues the New York times and certain of its employees}

A front- page article published in the New York Times was under the title "Years of Questions but Researcher Gets a pass." Due to that publication, Dr. Carlo M. Croce, a cancer researcher at The Ohio State University presented a complaint of defamation against it. 


\section{Conveyed Meaning}

The implicit meaning of the above statement is to make millions of people feel doubtful of Dr. Croce's research and motivate people to ask about whether Ohio State University has financial motives concerning his work.

Publishing the same article with or without modifications through the New York times, the social media like Twitter and Facebook, interviews, and letters were to expose Dr. Croce although he had been researching cancer, and specifically cancer genetics for 45 years; he had been recognized as a pioneering scientist who made fundamental contributions in the areas of oncology, genetics and developmental biology which had already had a major impact in the diagnosis, prognosis and treatment of cancer; and he had received a number of awards recognizing his research and discoveries.

Another article was published under another headline: "A star cancer researcher accused of fraud was repeatedly cleared by Ohio State, which reaps millions from his grants." In this article, Dr. Croce was described as being productive in his scientific field, that's why, Ohio State exploited that feature to benefit from his fame financially.

Speech acts: reporting fact vs. giving opinion

Dr. Croce alleges that the letter sent to him from one of the New York Times employees, James Glanz included several defamatory statements. For example, "Dr. Sanders argues... that Dr. Croce is knowingly engaging in scientific misconduct and fraud. Does Dr. Croce disagree with this allegation, and if so, why?"

Dr. Croce refuted the false and defamatory allegations in the letter.

Dr. Croce requested information supporting some of the statements made in the letter.

"A star cancer researcher accused of fraud was repeatedly cleared by Ohio State, which reaps millions from his grants."

Dr. Croce asserted state law claims for defamation, false light and intentional infliction and emotional distress. He alleged that he had lost Weight and sleep since he was embarrassed by the fact that millions of people worldwide had read the article which harmed and defamed him not only as a scientist and as a person but his life's work. This is the perlocutionary act.

\section{Malicious Language}

Those defamatory statements exposed Dr. Croce to public hatred, contempt, ridicule, shame or disgrace, and it affects him adversely in his trade, business or profession.

Intentionality and Discourse Structure and Framing

The New York Times and its employees' intentions were clear through the topics shown like planting suspicion in other people's minds against Dr. Croce's medical researches and accusing Ohio State University of making use of his works financially. Thus, two main topics were deception and fraud from the side of Dr. Croce.

\subsection{Arabic Defamation Cases}

In the present study, there are five defamation cases which are selected to be analyzed and discussed:

\subsubsection{A Student Shouts Loudly at Chemistry Teacher}

One of the secondary school students, Sajad, shouted at a Teacher of Chemistry, Mr. Rahman, loudly in the class in front of all the students at the second year, saying:

\section{"We don't have money like Ahmed Sa'ad."}

\section{(qabil ?iHna 9idna fluus miӨil ?aHmed sa9ad.).}

The criminal legislator criminalizes any act committed against the educational official during doing his duty or because of doing his duty (Al-Haydary and Betti, 2020b: 36).

Grammatical referencing

Referring to the name of that student in particular was to put a focus on him. He was too lazy especially in Chemistry but he succeeded in that material with high marks. This was what was said against the student, Ahmed Sa'ad.

Speech acts: reporting fact vs. giving opinion

Sajad accused a teacher of Chemistry as a bribee and that student, Ahmed Sa'ad, as a briber because they committed a bribery crime. 


\section{Conveyed Meaning}

The statement said by the student, Sajad, is an accusation of bribery crime against the teacher and the student, Ahmed. Sajad told the teacher that he and other students did not have money like Ahmed to give you and pass the exam of Chemistry.

Discourse Structure and Framing

The student, Sajad, was so lazy and he did not exert his efforts to pass the exam of Chemistry. So, he wanted to make a pressure on the teacher by embarrassing him when he shouted loudly and said that defamatory statement.

Finally, it was proved that the statement was false.

\subsubsection{A Lawsuit Against a Professor}

A university professor of mathematics, Dr. Anees taught fourth-year students. A group of students failed in his exam. One of those failed students, Hasan, began talking among people that the professor had a forged certificate. In addition, Hasan's brother published in the Facebook that Dr. Anees is a bribee.

Speech Acts: Reporting Fact vs. Giving Opinion

Hasan and other students alleged that Prof. Dr. Anees had a forged certificate. Hasan's brother accused Dr. Anees of being a briber. Such an allegation and an accusation destroyed his academic reputation and scientific fame among people in his community.

"Our Professor is giving us lectures with his forged certificate. Not only this, he is also a bribee."

\section{(?ustaðana ya9Tina muHaDarat wa Jahadatahu muzawara. laysa haða faqaT bal kawnahu murtafy.)}

\section{Malicious Meaning}

The failed students had an ill will and bad intention against their professor. Their accusations occurred with exaggeration to make people contempt, disrespect him and be away from his class. They behaved with him with malice.

As a result, those students were expelled from the school because the defamatory statements were false.

\subsubsection{A Hospital Head Files a Complaint Against a Worker}

A worker at a hospital, Salim, wanted to be granted more than one vacation in one month, the head of the hospital, Dr. Amir, rejected that.

Speech Acts: Reporting Fact vs. Giving Opinion

Among patients, workers, and hospital auditors, the cleaner, Salim, accused Dr. Amir of being addicted to booze. Such a defamatory statement was so difficult and dangerous for Amir's professional future; it injured his profession and damaged his reputation.

Malicious Language

From time to time, Salim said "our head of the hospital was addicted to booze."

\section{(mudirna bilmustaffa kan mudmin xamra.)}

In this defamatory statement, there was actual malice. It expressed hatred, contempt, ridicule, and obloquy.

Finally, Dr. Amir could prove the falsity of that defamatory statement and the cleaner was legally punished.

\subsubsection{A Shop Owner Files a Lawsuit Against a Man}

A lady who was a shop owner in a market, Rahima, borrowed one of her relatives, Ibrahim, an amount of money two years ago. Then she phoned him to ask him to give her back the money.

Grammatical Referencing

Ibrahim came to Rahima's shop said with a loud voice among tens of people in the middle of the market,

"Rahima, you did not borrow people money, take care of usury only."

(raHima ?inti wenit3 wen ?ilqurDa. ?ihtamy bas bilfayz.)

In addition to damaging her reputation among her inhabitants and relatives, Ibrahim wanted to insult her by mentioning a name of a lady in the market, Rahima.

Speech Acts: Reporting Fact vs. Giving Opinion 
One of the relatives, Ibrahim, accused Rahima of being usurer. Instead of giving her her right which was an amount of money borrowed by that man, he tried to destroy her honour, dignity, and consideration inside her community and to low and nothing in the eyes of others.

\section{Malicious Language}

Ibrahim did not want to give Rahima back her money, so he used a very tricky, willfully way make other people be doubtful of her. He was so exaggerative when he talked to her, mocking at her. Such a devilish behaviour made people avoid Rahima and they refused to deal with her commercially. Instead of being a successful merchant, she became hatred, contemptuous, ridiculous, and outcast.

\subsubsection{An Oil Company Manager Files a Complaint Against a Man}

A man, Mehdi, submitted for a job in an oil company but the manager of that company, Mr. Dakhil refused. That man published a defamatory statement in one of the social media, facebook:

"Mr. Dakhil, the manager, was one of the lords of prisons. But he was released before a short period of time."

\section{(dexiil ?almudiir kan min ?arbab ?alsid3uun wa qabil fatra ?aTliqaw saraHa.)}

Speech Acts: Reporting Fact vs. Giving Opinion

Mehdi accused the manager of the oil company, Mr. Dakhil, of being one of the lords of prisons. The manager was a prisoner and he was released before a short time. Such an accusation was published in the Facebook. The purpose beyond that accusation was to damage Mr. Dakhil's reputation among his inhabitants.

Conveyed Meaning

When Mehdi published the phrase "lords of prisons", he wanted to refer to Mr. Dakhil as a criminal. So, the people should be very careful in dealing with him commercially and financially.

Malicious Meaning

Mehdi was so cunning, wily to make the people be away from the manager of the oil company. He wanted him to be hatred, contemptuous, and obloquy. Mehdi willfully described Mr. Dakhil in this way to defame him, to affect his consideration and dignity negatively.

\section{Conclusions}

The conclusions of the present study are represented by the similarities and differences between English and Arabic in terms of defamation:

1. English and Arabic are similar to each other in terms of the legal language and its features.

2. Defamation is rejected by both communities: English and Iraqi-Arabic but in Iraq, it is totally refused by its inhabitants.

3. The law of defamation is exceedingly described as being complex and it is greatly different from a state to a state.

4. To be defamatory, there should be an imputation of blameworthy conduct rather than the statement which injures someone's trade or business.

5. It is so difficult to interpret defamatory language but there are different techniques followed to make it easy like certainty, the tendency of words to cause loss in addition to the degree of malice which is involved. In fact, interpretation and policy are related to each other in the way that the reasonable reader test means. To determine the meaning of any statement, the court should say that the defendant must be responsible for the meaning of the defamatory statements.

6. Some disclosed and discreditable information revealed would harm or embarrass the victim in a public way.

7. English and Arabic agree on the locutionary, illocutionary, and perolcutionary acts. The same is with direct and indirect speech acts. But they are different from each other in terms of the way of classifying speech acts.

8. In everyday communication, understanding any utterance relies on the conventional symbols used by speakers to communicate and our knowledge we have about speakers and the situation where an utterance is made. So, by knowledge, the speaker's intention to convey is to be revealed.

9. In both languages, defamation is both illocutionary and perlocutionary acts. If there is no perlocutionary act, there is no verbal offence. The perlocutionary act is the characteristic feature of the verbal offence. 
10. English defamation cases include speech acts more than Arabic defamation cases.

11. In terms of defamation, English and Arabic are similar to each other in having speech acts, grammatical referencing, conveyed meaning, malicious meaning, and discourse structure and framing with intentionality. This point refutes the study hypothesis which is English and Arabic are different from each other in terms of defamation. The two languages are similar in terms of defamation pragmatically.

12. In both English and Arabic defamation cases, some defamatory statements are proved to be true or the accusations are false.

13. Cultural differences play an important role in differentiating between English and Arabic in terms of defamation. For example, working in saloons and brothels is socially forbidden and described as being against the norms and tradition in the Arabic communities while in the English communities, it is so normal to work in such places to keep living and to get money.

\section{Appendix (I): A List of Arabic Symbols}

(Betti, 2015: 67; Betti, 2007: 409-410 and Al-Seady, 1998: 77)

\begin{tabular}{|c|c|c|}
\hline Arabic Symbol & Example & Meaning \\
\hline$?$ & /?ams & Yesterday \\
\hline $\mathrm{b}$ & bab & Door \\
\hline $\mathrm{t}$ & timman & rice \\
\hline$\Theta$ & Өa9lb & fox \\
\hline $\mathrm{d} 3$ & d3amaal & beauty \\
\hline $\mathrm{H}$ & Hariim & women \\
\hline $\mathrm{x}$ & xubuz & bread \\
\hline $\mathrm{d}$ & tdanna & Be nearby. \\
\hline ð & ðabha & He threw it. \\
\hline $\mathrm{r}$ & ramul & sand \\
\hline $\mathrm{z}$ & zraar & button \\
\hline $\mathrm{s}$ & suug & market \\
\hline $\int$ & Jmaalak & What is wrong with you? \\
\hline $\mathrm{S}$ & Sabur & patience \\
\hline $\mathrm{D}$ & DabuT & an officer \\
\hline $\mathrm{T}$ & TamaTa & tomato \\
\hline D & Daal & staying \\
\hline 9 & 9aali & High \\
\hline G & Graab & crow \\
\hline $\mathrm{f}$ & fiil & an elephant \\
\hline q & qadiim & old \\
\hline $\mathrm{k}$ & ka9ak & cake \\
\hline 1 & limna & gather us. \\
\hline $\mathrm{m}$ & maxadda & pillow \\
\hline $\mathrm{n}$ & nibaH & Barked \\
\hline h & hnaa & here \\
\hline $\mathrm{w}$ & warana & behind us \\
\hline $\mathrm{j}$ & yawm & day \\
\hline $\mathrm{g}$ & ga9ad & He set down. \\
\hline $\mathrm{p}$ & parda & Curtain \\
\hline $\mathrm{t} 3$ & t3aali & bank of the river \\
\hline i & mi9da & Stomach \\
\hline $\mathrm{a}$ & saliim & healthy \\
\hline $\mathrm{u}$ & ummii & My mother \\
\hline ii & biina & in us \\
\hline aa & saalim & Safe \\
\hline $\mathrm{uu}$ & 9uud & stick \\
\hline
\end{tabular}




\section{References}

Ahmed, G. (2013). Crimes of Insult, Defamation and Verbal Abuse: Commenting on Them by Rules of Reversal of a Sentence and High Administrative Court. Cairo: Centre of Administrative Police Information.

Al-Durra, M. A. S. (2009). Explaining Penal Code: The Private Section. Cairo: Al-Atik for Industrializing the Book.

Al-Haydary, Jamal I., \& Betti, Mohammed J. (2020a). The Objective Penalty Protection of the Responsibles for the Educational and Learning Process in Public Defamation. Multidisciplinary International Journal, 1(6), 15- 29.

Al-Haydary, J. I., \& Betti, M. J. (2020b). The Goals of the Law of Protection of Teachers, Supervisors and Educational Counselors No. (8) 2018 and Basis of Protection. International Journal of Law, Management and Social Science, 4(2), 25-38.

Al-Musawy, S. R. (2010). Crimes of Defamation and Verbal Abuse via Satellites: A Comparative Study Supported by Judicial Applications. Baghdad: Sabah Library.

Al-Qulaly, Mohammed M. (1948). In the Criminal Responsibility. Cairo: University of the First Fuad.

Al-Seady, Mohammed J. B. (1998). The Employment of English Lexicons by Adolescent Speakers of Nasiriya Iraqi Arabic as Determined by Sex Differentiation. Al-Qadisiya Journal, 3(2), 72-9.

Al-Seady, Mohammed J. B. (2002a). English Phonetics. Nasiriaya: Afaaq.

Al-Seady, Mohammed J. B. (2002b). Some Morphological, Lexical and Syntactic Aspects of the Interlanguage of Third Year Students/ Dept. of English/College of Education/ University of Qadisiya. Journal of Qadisiya for Educational Sciences, 2(1), 13-19.

Al- Timimy, Mahya bin Musa'd. (1982). Defamation rules in the Islamic legislation. Unpublished MA Thesis, Mecca, College of Islamic Legislation and Studies.

Amponsah, Peter, N. (2004). Libel Law, Political Criticism, and Defamation of Public Figures: The USE, Europe, and Australia. New York: LFB Scholarly Publishing LLC.

Austin, J. L. (1962). How to Do Things with Words. Harvard: The President and Fellows of Harvard College.

Betti, Mohammed J. (2007). Jokes in Iraq: A Study of Coherence and Cohesion. Journal of the College of Education, University of Wasit, 1(1), 399-411. https://doi.org/10.31185/eduj.Vol1.Iss1.694

Betti, Mohammed J. (2015). Jokes in Iraq: A Study of Coherence and Cohesion. In Betti \& Igaab (Eds.), Linguistic Studies (pp. 51-67). Diwaniyah: Nippur.

Betti, Mohammed J. (2019). The Objective Penalty Protection of the Responsibles for the Educational and Learning Process. Unpublished MA thesis, Najaf, Al- Alamein Institute of Higher Studies.

Betti, Mohammed J., \& Al-Jubouri, Chasib, F. ( 2009). A Structural and Intonational Study of Theme and Rheme in Iraqi Advanced EFL Learners' Language Repertoire. Alilbayt Journal, 7, 363-379.

Betti, M. J., \& Al-Jubouri, C. F. (2015). Approaches and Methods of Teaching English As a Foreign Language. Diwaniya: Nippur.

Betti, M. J., \& Igaab, Zainab K. (2015). (eds). Linguistic Studies. Diwaniya: Nippur.

Betti, M. J., \& Hashim, T. G. (2018). The Lawyer's Discourse in the Courtroom: A Contrastive Study in English and Arabic. International Journal of English Linguistics, 8(3), 276-296. https://doi.org/10.5539/ijel.v8n3p276

Betti, M. J., \& Igaab, Zainab K. (2018). A Contrastive Study of Modulation in English and Arabic. International Journal of English and Cultural Studies, 1(1), 30-45. https://doi.org/10.11114/ijecs.v1i1.3120

Betti, M. J., \& AlFartoosy, M. H. H. (2019). Ellipsis and Reiteration in English and Arabic: A Contrastive Study. English Language and Literature Studies, 9(1), 93-105. https://doi.org/10.5539/ells.v9n1p93

Betti, M. J. H., \& Ahmed, A. (2020). The Iraqi EFL Learners' Ability to Use Speech Acts in MA and Ph.D. Theses Defense. Education, Language and Sociology Research, 1(2), 41-65. https://doi.org/10.22158/elsr.v1n2p41

Betti, M. J., \& Mahdi, M. A. (2020). A Conversation Analysis of Repair Trouble Sources, Inadequacy and Positions in the Iraqi University Viva Discussions in English. International Linguistics Research, 3(4), 69-93. https://doi.org/10.30560/ilr.v3n4p69 
Betti, M. J., \& Yaseen, K. S. (2020). The Iraqi EFL Learners' Use of Conversational Maxims at the University Level. Education, Language and Sociology Research, 1(1), 43-60. https://doi.org/10.22158/elsr.v1n1p43

Bies, R. J., \& Thomas, M. T. (1993). Employee-initiated defamation lawsuits: Organizational responses and dilemmas. Employee Responsibilities and Rights Journal, 6(4), 313-324. Plenum Publishing Corporation. https://doi.org/10.1007/BF01385020

Calow, Duncan. (1995). Internet liability: defamation on the internet. The Computer Law and Security Report. Denton Hall, 11, 199- 201. https://doi.org/10.1016/S0267-3649(00)80048-5

Dehham, S. H., Betti, M. J., \& Hussein, N. M. (2021). The Effect of Using Estafet Writing Technique to Enhance Students' Compositional Efficiency. Education, Language and Sociology Research, 2(1), 1-13.

Duffy, D. J. (1983). Defamation. Privacy in Work Place, 3, 267- 280. https://doi.org/10.1002/ert.3910100307

Garner, B. A. (2009). Black's law Dictionary. New York: A Thomson Reuters Business.

Ibrahim, M. S. (1997). Press Freedom: A Study in the Legislating Politics and its Relation to Democratic Development. Cairo: Scientific Books House.

Igaab, Zainab K. (2010) Reduplication in English and Arabic: A Contrastive Study. Journals Education for Girls, $1(1), 3-24$.

Igaab, Zainab K., \& Altai, S. M. M. (2018). Concord in English and Arabic: A Contrastive Study. International Journal of English Linguistics, 8(2), 288-297. https://doi.org/10.5539/ijel.v8n2p288

Igaab, Zainab K., \& Hanan, A. (2018). Collocation in English and Arabic: A Contrastive Study. English Language and Literature Studies, 8(4), 89-103. https://doi.org/10.5539/ells.v8n4p89

Igaab, Zainab K., \& Israa, K. (2018). Affixation in English and Arabic: A Contrastive Study. English Language and Literature Studies, 8(1), 92-103. https://doi.org/10.5539/ells.v8n1p92

Igaab, Zainab K., \& Tarrad, I. R. (2019). Pronouns in English and Arabic: A Contrastive Study. English Language and Literature Studies, 9(1), 53-69. https://doi.org/10.5539/ells.v9n1p53

Kenyon, Andrew, T. (2010). What conversation? free speech and defamation law. The Modern Law Review, 73(5), 697-720. Oxford: Blackwell Publishing. https://doi.org/10.1111/j.1468-2230.2010.00815.x

Mitchell, P. (2005). The Making of the Modern Law of Defamation. Oxford: HART Publishing.

Mousa, Mahmood S. (2012). Rules of Criminalization and Strict Liability: A Comparative Study in Arab Legislations and Italian and French Laws. Al-Iskandariya: House of University Printings.

Naseef, Nasha't A. (2010). Explaining Penal Code: The Private Section. Cairo: Al- Sanhoory Library.

Rolph, D. (2008). Reputation, Celebrity and Defamation Law. England: Ashgat Publishing Limited.

Salman, Hussien Salah and Mohammed Jasim Betti (2020). Politeness and Face Threatening Acts in Iraqi EFL learners' Conversations. Glossa, 3(8), 221-233.

Searle, J. (1969). Speech acts: In The Philosophy of Language. Cambridge: CUP. https://doi.org/10.1017/CBO9781139173438

Shuy, Roger, W. (2000). The language of Defamation Cases. Oxford: OUP.

Tiersma, P. M. (1987). The Language of Defamation. Law Review, 66, 303-350.

Tiersma, P. M. (2015). Defamatory language and the act of Accusing. In Speaking of Language and Law: Conversations on the Work of Peter Tiersma.

\section{Copyrights}

Copyright for this article is retained by the author(s), with first publication rights granted to the journal.

This is an open-access article distributed under the terms and conditions of the Creative Commons Attribution license (http://creativecommons.org/licenses/by/4.0/). 